\title{
Teacher Education Freshmen Applicants' Current State in the New Normal's Learning Delivery Platforms
}

\author{
Mark Angelo C. Reotutar \\ University of Northern Philippines, Philippines \\ markangelo.reotutar@unp.edu.ph
}

\begin{abstract}
The online learning platform (OLS) is currently the new normal learning setting amidst the Covid-19 pandemic. Teachers need to look on the other side of the traditional classroom-based learning mode to make teaching and learning in the new normal possible. It aimed to analyze the current state of the teacher education freshmen applicants concerning the new normal learning platforms. This study employed a descriptive method of research and considered a sample of 85 freshmen applicants in the College of Teacher Education in the academic year 2020-2021. The frequencies and percent value was used to analyze the data gathered. The following are the verdicts of the study, the bulk of the respondents belong to low-income families with farming as their family source of income. Most of the respondents have their mobile phones while the great majorities are using mobile data only. All of the respondents do not have any idea about the different platforms in online learning. Based on the findings, the researcher concluded that the freshmen applicants in the College of Teacher Education cannot totally survive and are not yet ready to embrace the new normal learning platforms due to poverty and lack of resources. It is therefore recommended that the University administration needs to open other sources of learning platforms such as the use of printed learning materials of which will be delivered door-to-door to the students. Besides, the College of Teacher Education should plan and initiate on how to make learning flexible and more engaging.
\end{abstract}

Keywords

COVID-19 pandemic; freshmen applicants' profile; new normal; readiness on the online learning platform; survey research; quantitative method

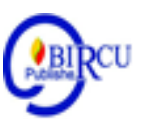

\section{Introduction}

Education is very important to human beings especially to youngsters because this serves as their stepping-board in achieving their goals in life. It is so hard to imagine if education stops.

At present, all countries in the world are facing a national health emergency because of the Covid-19 (Corona Virus) pandemic which was originated in the province of Wuhan in China. This disease causes a lot of circumstances such as lung infections, flu, fever, and sometimes death. The World Health Organization reiterated that "the COVID-19 is an infectious disease caused by a newly discovered coronavirus." They also added in their report that those who were infected in the virus experienced a mild to moderate respiratory illness and recovered without requiring special treatment and stressed that those older people and those with underlying medical problems such as cancer, diabetes, chronic respiratory and cardiovascular diseases are more probable to develop serious illness. As per suggestions, the best way to prevent and slow down the transmission is to be more learned about the COVID19 virus especially how it causes and how it extends. It can also be noted that the virus can be 
transmitted through droplets of saliva or any discharge from the nose when an infected person coughs or sneezes. On the other side, according to Wahid, R., Pribadi, F., \& Wakas, B. E. (2020), the virus has related the swiftly growing use of social media/internet, the life of a distance gaining knowledge of system (online) proving that this pandemic has targeted on gaining knowledge of moving from traditional to distance or online (with inside the network).

Due to the Covid-19 pandemic, the Philippine President Rodrigo Roa Duterte with the help and advice of the Department of Health (DOH) and the Inter-Agency Task Force (IATF) imposed an Enhanced Community Quarantine (ECQ) in high-risk areas of the country. In lieu, schools under ECQ suspended classes and implemented other platforms of learning to continue and finish the school year. Many teachers struggled as to how they will continue and deliver their instructions. Many students appeared and asked considerations for they cannot submit their expected final outputs because of the lack of resources.

The Commission on Higher Education (CHED) especially in the Regional Office 1, employed free webinars twice a week for faculty and staff to help them learn and apply the suggested new learning delivery modes amidst the Covid-19 pandemic. The University of Northern Philippines also conducted one (1) month pieces of training and workshops about online teaching and learning to cater to the needs of the faculty and staff as to their preparations for the Academic Year 2020-2021.

Despite the so many preparations not only in the University of Northern Philippines but also in other States, Universities, and Colleges (SUC), we do not know if all of these will work considering the present situations of our learners. Meanwhile, entering the next educational level is difficult because we need again to adjust not only to our physical and mental being but also in our emotions because of the new environment. However, it is more difficult if we include new platforms of learning knowing that we don't have any means to do it.

This is the reason why the researcher wants to know the status of the students specifically the Teacher Education freshmen applicants as to how they are prepared in the new normal platforms of learning. In the conceptualization of this study, the researcher studied selected concepts and researches which have bearing on the research.

On the report of Ajzen, (1991), he elaborated that the theory of planned behavior (TPB) argues that individual attitude toward the behavior can determine individual behavior. "Social Cognitive Theory (SCT) explicates about human behaviors through the following interacting factors: cognitive, affective and biological events; environment, and behavior" (Compeau \& Higgins, 1995).

According to Teresita Tanhuenco-Tumapon (July 4, 2020), what has become 'normal' is all about lockdowns, quarantines, masks, washing hands, taking vitamins and nutrient-rich food to nurture health, covering a coughing mouth and sneezing nose, physical distancing, and the omnipresent support technology is a "must" to continue for a lifetime. These and more compose the new normal. Before Covid-19, Industry 4 (the robot age) of Agenda 2030, robotics was already a popular focus; much more at this time where robots execute routine jobs. Nowadays, robots serve in healthcare, social work, business and trade, food, and other aspects of human activity. Various organizations/companies are resorting to virtual private networks and voice-over protocols, especially that meetings, negotiations, consultations are mostly virtual. She also mentioned about what Dr. Henry Chan wrote in his report in The Manila Times last May 10, 2020, that telecommuting represents a new paradigm in office work and if remote work becomes more common after the Covid-19 pandemic, employers may decide to reduce lease costs and hire people from regions with cheaper labor costs. 
Moreover, Tumapon (2020) also reported that several tertiary and basic institutions have deferred graduation to the next school year (SY).

Blended learning generates a 'rich' educational environment with various technologies that enable communication in both face-to-face and virtual teaching. The physiognomies of the students are closely related to the learning effectiveness in the blended learning environment. Students' ability to direct themselves in learning and to utilize learning technologies can affect student learning effectiveness (Shuang Geng, Kris M.Y. Law \& Ben Niu, 2019). Blended Learning (BL) creates a rich educational environment enabling various forms of communication by combining face-to-face learning with technologically boosted learning so that instruction and learning occur both in the classroom and online (Collis \& Moonen, 2012). More so, a blended learning course lies between a continuum anchored at opposite ends by entirely face-to-face and fully online learning environments (Rovai \& Jordan, 2004). The effective integration of the face-to-face and Internet Technology (IT) components determines the quality of course design so that blended learning is not just an add-on to the existing dominant approach or method (Garrison \& Kanuka, 2004).

In the online learning scenarios according to Khan (2009) where the building of an online curriculum is mostly instinctive. Moreover, students have more elasticity in deciding when, how, and with what content and actions they engage (Milligan \& Littlejohn, 2014). This flexibility requires students to monitor and adjust their behavior and actions concerning the specific learning context (Zimmerman, 2000). Students are aware of their learning responsibility in themselves instead of an external source, such as a teacher (Demir, 2015). "A self-directed learner tends to actively engage in the learning processes, such as acquiring information, planning, and evaluating the learning activities. Active learning strategies can raise students' participation and improve the learning (Freeman, S., Eddy, S. L., McDonough, M., Smith, M. K., Okoroafor, N., Jordt, H., et al. (2014); Yilmaz, 2016). However, not much empirical evidence is available in the extant literature regarding the impact of self-direct learning in the blended learning setting."

"Readiness in technology is considered a critical aspect related to students' learning in the blended learning atmosphere. The emergence of various computer technologies enables the usage of multimedia content and multimedia communication (Horton, 2006) for education, and offers anywhere, anytime access to the learning content."

It also refers to one's willingness to control new technologies in performing tasks (Parasuraman, 2000). Web-based technologies, though well established, still face the challenge of being readily accepted when introduced to a new application setting. Compared to traditional classroom learning, students' readiness to accept and utilize web-based learning resources varies across individuals. Students' attitude toward technology-based applications reflects their technology readiness in the learning circumstances. Lastly, Cheon, Lee, Crooks, and Song (2012) established that college students' attitude positively influences their intention to adopt mobile learning.

Technology in teaching should be studied not only its literal used but also in deeper perspectives. Makhroji, I. (2020) concluded in his study that using a technology such as the Edmodo-based application in online learning can increased students' morals such as honesty, responsibility and discipline.

\subsection{Objectives of the Study}

Generally, this study aimed to analyze the present status of the selected freshmen applicants in the College of Teacher Education during the first term of the academic year 2020-2021. Specifically, it described the profile of the respondent as to their chosen program and field of specialization; general weighted average; parents' occupation and monthly net 
income; the number of siblings in the family. It also described the current status of the respondents as to their available accessories, gadgets, and software to be used in their online classes; availability of internet access; the presence of their social media accounts in preparation to the new normal learning delivery model to be employed in the university; and lastly to determine their awareness on the different available online learning platforms.

\section{Research Methods}

\subsection{Sampling of the Study}

Eighty-five (85) freshmen applicants in the College of Teacher Education during the first term of the academic year 2020-2021 were randomly selected and served as the respondents of this study.

\subsection{Research Design}

The researcher made use of the descriptive process of investigation was castoff in the study since it involves gathering information by examining the status of teacher education freshmen applicants as to their readiness in the new normal learning platforms.

\subsection{Research Instrument}

The research instrument used in the study was the adopted Application Form for College Admission of the University of Northern Philippines.

\subsection{Data Analysis}

The data collected were analyzed using frequencies and percentages.

\subsection{Ethical Considerations}

Consent letters were given to all participants before the conduction of the survey. Information such as the participant's name and address were kept confidential and would never be disclosed to anybody.

\section{Discussion}

This segment presents the findings of the study.

Table 1. Distribution of the Respondents' Profile

\begin{tabular}{|c|c|c|}
\hline \multicolumn{1}{|c|}{ Profile of the Respondents } & f & \% \\
\hline Program/Course & & \\
\hline Bachelor of Early Childhood Education (BECED) & 3 & 3.53 \\
\hline Bachelor of Special Needs Education (BSNED) & 2 & 2.35 \\
\hline Bachelor of Elementary Education (BEED) & 2 & 2.35 \\
\hline Bachelor of Physical Education (BPEd) & 5 & 5.88 \\
\hline Bachelor of Secondary Education (BSEd) & 61 & 71.77 \\
\hline Bachelor of Technical-Vocational Teacher Education (BTVTEd) & 5 & 5.88 \\
\hline Bachelor of Technology and Livelihood Education (BTLEd) & 7 & 8.24 \\
\hline Total & $\mathbf{8 5}$ & $\mathbf{1 0 0 . 0 0}$ \\
\hline Field of Specialization & $\mathbf{f}$ & $\mathbf{\%}$ \\
\hline Early Childhood Education & 3 & 3.53 \\
\hline Special Needs Education & 2 & 2.35 \\
\hline
\end{tabular}




\begin{tabular}{|c|c|c|}
\hline Elementary Education & 2 & 2.35 \\
\hline Physical Education & 5 & 5.88 \\
\hline Mathematics & 6 & 7.06 \\
\hline Science & 12 & 14.12 \\
\hline English & 19 & 22.35 \\
\hline Filipino & 17 & 20.00 \\
\hline Social Science & 7 & 8.24 \\
\hline Beauty Care and Wellness & 5 & 5.88 \\
\hline Home Economics & 7 & 8.24 \\
\hline Total & 85 & 100.00 \\
\hline General Weighted Average & $\mathbf{f}$ & $\%$ \\
\hline $85-89$ & 38 & 44.71 \\
\hline $90-94$ & 41 & 48.24 \\
\hline $95-99$ & 6 & 7.06 \\
\hline Total & 85 & 100.00 \\
\hline Parents' Occupation & f & $\%$ \\
\hline \multicolumn{3}{|l|}{ Father } \\
\hline Teaching & 2 & 2.35 \\
\hline Farming & 67 & 78.82 \\
\hline Driving & 7 & 8.24 \\
\hline None & 9 & 10.59 \\
\hline Total & 85 & 100.00 \\
\hline \multicolumn{3}{|l|}{ Mother } \\
\hline Farming & 51 & 60.00 \\
\hline Business woman & 9 & 10.59 \\
\hline None & 25 & 29.41 \\
\hline Total & 85 & 100.00 \\
\hline \multicolumn{3}{|l|}{ Average Monthly Family Income } \\
\hline Below 2000 & 10 & 11.76 \\
\hline $2000-3999$ & 49 & 57.65 \\
\hline $4000-5999$ & 24 & 28.24 \\
\hline 6000 and above & 2 & 2.35 \\
\hline Total & 85 & 100.00 \\
\hline Number of Siblings & f & $\%$ \\
\hline Only child & 9 & 10.59 \\
\hline $1-2$ & 43 & 50.59 \\
\hline $3-4$ & 26 & 30.59 \\
\hline 5 and above & 7 & 8.23 \\
\hline Total & 85 & 100.00 \\
\hline
\end{tabular}

Table 1 presents the respondents' chosen program and field of specialization, their general weighted average, their parents' occupation and monthly net income, and their number of siblings in the family.

It can be gleaned from the table that the majority of the respondents decided to take the BSEd program (61 or $71.77 \%$ ) while a substantial percentage of the respondents where plotted in the other programs, respectively. As per the replies of the respondents during the phone call interview, they preferred to teach in secondary high school because based on their 
observations, secondary students are easy to handle as compared to elementary pupils. Moreover, the majority of respondents also pointed out that they only want to teach their favorite subjects which is their chosen field of specialization.

In terms of the field of specializations offered in the College of Teacher Education, the majority of the respondents applied in the English (19), Filipino (17), and science (12) fields. Surprisingly, there were 6 or $7.06 \%$ of respondents have a General Weighted Average of 95 and above. This could mean that these respondents were excelling and with the highest honors during their senior high school days. On the other side, the majority of the fathers and mothers of the respondents are farmers $(67$ or 78.82 percent and 51 or 60 percent, respectively). This could imply that majority of the parents' source of income is seasonal basis depending on how many times they plant in a year. Almost all of the respondents' family income ( 83 or $97.65 \%$ ) are below 6000 pesos a month. Lastly, most of the respondents have siblings.

Table 2. Distribution of the Respondents' Current Status in Preparation for the New Normal Online Learning Delivery Mode

\begin{tabular}{|l|c|c|}
\hline Current Status of the Respondents & f & \% \\
\hline Available Accessories, Gadgets and Software being used* & & \\
\hline Microphone & 1 & 1.18 \\
\hline Headphone & 70 & 82.35 \\
\hline Webcam & 12 & 14.12 \\
\hline Audio and video editing software & 54 & 63.53 \\
\hline Screen Recorder & 43 & 50.59 \\
\hline Lightings & 2 & 2.35 \\
\hline Mobile Phone & 78 & 91.76 \\
\hline Tablet & 3 & 3.53 \\
\hline Laptop & 2 & 2.35 \\
\hline Desktop & 1 & 1.18 \\
\hline None & 8 & 9.41 \\
\hline Internet Access* & & \\
\hline Mobile Data & 73 & 85.88 \\
\hline Wifi (Prepaid) & 2 & 2.35 \\
\hline Wifi (Postpaid) & 3 & 3.53 \\
\hline None & 12 & 14.12 \\
\hline Social Media Accounts* & & \\
\hline Facebook & 85 & 100.00 \\
\hline Gmail & 70 & 82.25 \\
\hline Yahoo mail & 59 & 69.41 \\
\hline Youtube & 40 & 47.06 \\
\hline Viber & 2 & 2.35 \\
\hline Instagram & 53 & 62.35 \\
\hline Twitter & 38 & 44.71 \\
\hline
\end{tabular}

\footnotetext{
*-Multiple Response
} 
It further shows that the distribution of the respondents' current status in preparation for the New Normal online learning delivery mode. It can be observed from Table 2 that most of the respondents (78 or $91.76 \%$ ) have their mobile phones while a great majority of them (70 or $82.35 \%$ ) have headsets. It is also important to note that only 3 of the group of respondents have their laptops/desktops which is clear that only these three respondents can open other important applications and programs which are far more versatile during the online class. It is important to note according to Stone (2020) that laptops/desktops raise collaboration with peers and teachers - especially if a student is choosing to take the lesson out of the classroom. The use of laptops within education allows for more engagement between students and makes for a more interesting learning experience.

Moreover, it also promotes 21st-century skills such as critical thinking, independent research, and cross-technology proficiency. These technologies also allow teamwork and student interaction. It helps students progress their critical skills that are demanded within the 21 st-century working environment. Surprisingly, there are still respondents (8 or $9.41 \%$ ) who don't have any technology at home which can be used for their online classes.

In terms of the availability of internet access, a great majority of the respondents ( 73 or $85.88 \%$ ) are using mobile data from their mobile phones when doing a web search. However, there was 12 or 14.12 percent of respondents who don't have internet access.

To last, all of the respondents have Facebook accounts which signify that Facebook application is the most commonly used social networking in the world. A great percentage of the respondents have their Youtube, Viber, and Twitter accounts (40 or $47.06 \%, 2$ or $2.35 \%$, and 38 or $44.71 \%$ ).

Table 3 displays the awareness of the respondents on the different available online learning platforms.

Table 3. Awareness of the Different Available Online Learning Platforms

\begin{tabular}{|l|c|c|c|c|}
\hline \multirow{2}{*}{ Online Learning Platforms } & \multicolumn{2}{|c|}{ Aware } & \multicolumn{2}{c|}{ Not Aware } \\
\cline { 2 - 5 } & f & \% & f & \% \\
\hline Google Classroom & 2 & 2.70 & 83 & 97.30 \\
\hline Docebo & -- & -- & 85 & 100.00 \\
\hline WizIQ & -- & -- & 85 & 100.00 \\
\hline Adobe Captivate & -- & -- & 85 & 100.00 \\
\hline Elucidat & -- & -- & 85 & 100.00 \\
\hline Articulate 360 & -- & -- & 85 & 100.00 \\
\hline Active 360 & -- & -- & 85 & 100.00 \\
\hline Shift & -- & -- & 85 & 100.00 \\
\hline Lectora Inspire & -- & -- & 85 & 100.00 \\
\hline Blackboard Learn & -- & -- & 85 & 100.00 \\
\hline LearnWorlds & -- & -- & 85 & 100.00 \\
\hline Coursera & -- & -- & 85 & 100.00 \\
\hline Thinkific & -- & -- & 85 & 100.00 \\
\hline SkillShare & -- & -- & 85 & 100.00 \\
\hline Teachable & -- & -- & 85 & 100.00 \\
\hline Kajabi & -- & -- & 85 & 100.00 \\
\hline Learn Dash & -- & -- & 85 & 100.00 \\
\hline Podia & -- & -- & 85 & 100.00 \\
\hline Memberium & -- & -- & 85 & 100.00 \\
\hline Ruzuku & -- & -- & 85 & 100.00 \\
\hline
\end{tabular}




\begin{tabular}{|l|c|c|c|c|}
\hline Shaw Academy & -- & -- & 85 & 100.00 \\
\hline LinkedIn Learning & -- & -- & 85 & 100.00 \\
\hline Treehouse & -- & -- & 85 & 100.00 \\
\hline Academy of Mine & -- & -- & 85 & 100.00 \\
\hline Member mouse & -- & -- & 85 & 100.00 \\
\hline Udemy & -- & -- & 85 & 100.00 \\
\hline Codeacademy & -- & -- & 85 & 100.00 \\
\hline Open-Edx & -- & -- & 85 & 100.00 \\
\hline Pluralsight & -- & -- & 85 & 100.00 \\
\hline Future Learn & -- & -- & 85 & 100.00 \\
\hline
\end{tabular}

As seen from the table, almost all of the respondents were not aware nor familiar in the listed online platforms which can be used to deliver the instruction for this new normal. Two (2) or $2.70 \%$ respondents were very much familiar with the Google classroom platform which means that the two respondents already had a piece of background knowledge about the Google classroom. The researcher asked a question regarding this matter during the phone call interview and he found out that these two respondents were previously using the Google classroom in their school.

\section{Conclusion}

In place of the findings, the researcher established that the freshmen applicants in the College of Teacher Education cannot totally survive and not yet ready with the recommended learning platforms in the new normal. It is therefore recommended that the University administration needs to open other sources of learning platforms such as the use of printed handouts, worktext, and learning modules of which will be delivered door-to-door to the students. Also, the College of Teacher Education should plan and initiate on how to make learning more flexible and more engaging.

\section{References}

Ajzen, I. (1991). The theory of planned behavior. Organizational Behavior and Human Decision Processes, 50, 179-211.

Cheon, J., Lee, S., Crooks, S. M., \& Song, J. (2012). An investigation of mobile learning readiness in higher education based on the theory of planned behavior. Computers \& Education, 59(3), 1054-1064.

Collis, B., \& Moonen, J. (2012). Flexible learning in a digital world: Experiences and expectations. London and New York: Routledge, Taylor \& Francis Group.

Compeau, D., \& Higgins, C. (1995). Computer Self-efficacy: Development of a Measure and Initial Test. Management Information Systems Quarterly, 19(1), 9.

Demir, O. (2015). The Investigation of E-learning Readiness of Students and Faculty Members: Hacettepe University Faculty of Education Example [Master Thesis]. Ankara: Hacettepe University.

Freeman, S., Eddy, S. L., McDonough, M., Smith, M. K., Okoroafor, N., Jordt, H., et al. (2014). Active Learning Increases Student Performance in Science, Engineering, and Mathematics. Proceedings of the National Academy of Sciences, 111(23), 8410e8415. 
Garrison, R., \& Kanuka, H. (2004). Blended Learning: Uncovering its Transformative Potential in Higher Education. Internet and Higher Education, 7, 95-105.

Geng, S., Law, K.MY., and Niu, B. (2019). Investigating self-directed learning and technology readiness in blending learning environment. International Journal of Educational Technology in Higher Education. Retrieved from https://educationaltechnologyjournal.springeropen.com/articles/10.1186/s41239-0190147-0.

Horton, W. (2006). E-learning by Design. San Francisco: Pfeiffer.

IATF (2020). Resolution No. 56 Series 2020. Retrieved from https://www.officialgazette.gov.ph/downloads/2020/07jul/20200716-IATFRESOLUTION-NO-56.pdf.

Khan, I. M. (2009). An analysis of the Motivational Factors in Online Learning. Doctoral Dissertation. Arizona: University of Phoenix.

Makhroji, I. (2020). Improving Character Education Strengthening through EDMODO-Based E-learning. Budapest International Research and Critics Institute (BIRCI Journal): Humanities. Volume 3, No. 3: 2262-2267.

Milligan, C., and Littlejohn, A. (2014). Supporting Professional Learning in a Massive Open Online Course. The International Review of Research in Open and Distributed Learning, 15(5). https://doi.org/10.19173/irrodl.v15i5.1855.

Parasuraman, A. (2000). Technology Readiness Index (TRI) a Multiple-item Scale to Measure Readiness to Embrace New Technologies. Journal of Service Research, 2(4), 307-320.

Rovai, A. P., and Jordan, H. (2004). Blended Learning and Sense of Community: a Comparative Analysis with Traditional and Fully Online Graduate Courses. The International Review of Research in Open and Distributed Learning, 5 (2). Retrieved from https://doi.org/10.19173/irrodl.v5i2.192.

Stone. (2020). Computer in the Classroom: Desktop vs. Laptop vs. Tablet. Retrieved from https://www.stone group.co.uk/insights/computers-in-the-classroom.

Tumapon, T.T. (2020). Education and the 'New Normal.' Manila Times. Retrieved from https:/www.manilatimes.net/2020/06/04/campus-press/education-and-the-newnormal/729288.

Wahid, R., Pribadi, F., and Wakas, B. E. (2020). Digital Activism: Covid-19 Effects in Capus Learning. Budapest International Research and Critics in Linguistics and Education. (BIRLE-Journal) Volume 3, No. 3: 1336-1342.

Retrieved from http//www.bircu-journal.com/index.php/birle/article/view/1174.

World Health Organization (2020). Coronavirus. Retrieved from https:/www.who.int/healthtopics/coronavirus\#tab=tab_1.

Yilmaz, R. (2016). Knowledge sharing behaviors in the e-learning community: Exploring the role of academic self-efficacy and sense of community. Computers in Human Behavior, $63,373 \mathrm{e} 382$.

Zimmerman, B. J. (2000). Attaining self-regulation: A social-cognitive perspective. In M. Boekaerts, P. R. Pintrich, \& M. Zeidner (Eds.), Handbook of self-regulation, (pp. 1339). San Diego: Academic. 